\title{
ACTS, THE LOGIC OF OBLIGATION, AND DEONTIC CALCULI
}

\author{
HÉCTOR-NERI CASTAÑEDA \\ Wayne State University
}

\section{Introduction}

My primary purpose here is to contribute to our understanding both of the concept of act and of a crucial principle of the logic of ordinary deontic language. This principle, qua analysandum can be put thus: (P) "If an act $\mathrm{A}$ entails and act $\mathrm{B}$, then the obligatoriness of $\mathrm{A}$ entails the obligatoriness of B." I will show that the term 'act' in (P) has to be understood as meaning what, for a lack of a better expression, I call "act prescriptively considered." I shall formulate five tests which jointly constitute a recursive characterization of what it is for an act to be prescriptively considered.

The discussion of acts prescriptively considered involves a criticism of the customary approach to the formalization of deontic logic. This approach ${ }^{1}$ has consisted, for the most part ${ }^{2}$, of attempts at furnishing a deontic interpretation for

1 See especially: G. H. von Wright, "Deontic Logic", Mind, vol, 60, 1951, pp. 1.15, An Essay in Modal Logic, North.Holland Publishing Co., Amsterdam, 1951, Ch. V; Alan Ross Anderson, The Formal Analysis of Normative Sys. tems, Technical Report No. 2, Interaction Laboratory, Yale University, New Haven, 1956, "Reduction of Deontic Logic to Alethic Modal Logic," Mind, Vol. 67, 1958, pp. 100-103; Arthur N. Prior, Formal Logic, 2nd. ed. Claredon Press, Oxford, England, 1962, Nicholas Rescher, "An Axiom System for Deontic Logic," Philosophical Studies, Vol. 9, 1958, pp. 24-30: Richard Montague, "Logical Necessity, Physical Necessity, Ethics, and Quantifiers," Inquiry, Vol. 4, 1960, pp. 259.269.

2 The exceptions known to me are: H. N. Castanieda, "The Logie of Obliga. tion," Philosophical Studies, Vol. 10, 1959, pp. 20-23, "Outline of a Theory on the General Structure of the Language of Action," Theoria, Vol. 26, 1960, pp. 151-182; Mark Fisher, "A System of Deontic-Alethic Modal Logic," Mind, Vol. 71, 1962, pp. 231-236, and R. Nozick and R. Routley, "Escaping the Good Samaritan Paradox," Mind, Vol. 71, 1962, pp. 377-382. I have a critical discussion of Fisher's paper in Journal of Symbolic Logic. 
the modal operator of calculi originally intended to formalize the logic of 'it is necessary that' or 'it is neccesarily the case that'. Almost all the resulting calculi have been severally criticized. ${ }^{3}$ My claim here is, however, that the customary approach is defective ab initio, because it fails to formalize the distinction between acts which are and acts which are not prescriptively considered.

Finally, I want to outline a better deontic calculus.

\section{A False Principle}

It seems evident that the entailments between deontic statements must follow the entailments of the acts these statements are about. Thus, a principle vaguely put as follows is fundamental to deontic logic:

(P) If an act A entails an act B, then (1) the obligatoriness of A entails the obligatoriness of $\mathrm{B}$, and (2) the forbiddnness (wrongness) of $\mathrm{B}$ entails the forbiddnness (wrongness) of $\mathrm{A}$.

But what is meant by an 'act A' here? Most of us have been trained to say that only states of affairs or statements have primarily entailment relationships, that other talk of entailment is derivative. Thus the most natural interpreta. tion of 'act A' here is 'statement or possible state of affairs to the effect that some agent performs A'. Thus, it is most natural to conceive of $(\mathrm{P})$ as a vague statement of the principle:

$\left(\mathrm{P}^{\prime}\right)$ If that a person $a$ performs act $\mathrm{A}$ entails that a person $b$ performs act $\mathrm{B}$, then: (1) $a$ is obligated (ought) to do A entails that $b$ is obligated (ought)

${ }^{3}$ See, e.g., E. J. Lemmon and Nowell-Smith, "Escapism: the Logical Basis of Ethics," Mind, Vol. 69, 1960, pp. 289-300; H.-N. Castañeda, "The Logic of Obligation", op. cit., pp. 17.20, "Obligation and Modal Logic," Logique et analyse, vol. 3, 1960, pp. 40-48; Alan Ross Anderson, "On the Logic of Com. mitment," Philosophical Studies, Vol. 10, 1959, pp. 23-27; N. Rescher, "Conditional Permission in Deontic Logic," Philosophical Studies, Vol. 13, 1962, pp. 1-6; A. R. Anderson, "Reply to Mr. Rescher," Ibid., p. 60.68; H. N. Castañeda, "Correction to 'The Logic of Obligation' (A Reply)." Philosophical Studies, Vol. XV, 1964, pp. 25.28. 
to do $\mathrm{B}$; and (2) that $b$ is forbidden (it is wrong for $b$ ) to do B entails that $a$ is forbidden (it is wrong for $a$ ) to do A.

A moment's reflection suffices, however, to realize that $\left(\mathrm{P}^{\prime}\right)$ is not equivalent to, much less is it the analisans of, (P). (P) is our protophilosophical datum, our analysan. $d u m$, and as such it expresses a true principle consistent with the deontic situations of practical life. On the other hand, $\left(\mathrm{P}^{\prime}\right)$ is not consistent with ordinary deontic situations: it leads to self-contradictions. To see this, suppose, for example, that:

(1) Arthur bandages Robert today, who cut himself and while shaving;

(2) Robert is identical with the man robbed (or who will be robbed) by Benjamin.

Then by the principle of substitution of identicals it follows from (1) and (2) that

(3) Arthur bandages today the man robbed (or who will be robbed) by Benjamin.

Obviously, (3) entails

(4) Benjamin has robbed (or will rob) someone.

Now, suppose that Arthur is obligated (in some sense or respect) to bandage Robert, because he is Robert's paid nurse, or because he has, as a good neighbor, the moral obligation to help a person in need, or because of something else. Then, by $\left(\mathrm{P}^{\prime}\right)$ Benjamin will be obligated (in the same sense or respect) to rob someone. But clearly, the deontic facts of daily life are such that in spite of (1)-(4) Benjamin may not only fail to have an obligation to rob, but probably has an obligation not to rob, in precisely the same sense or respect in which Arthur has an obligation to bandage Robert. This is a special case of the Good-Samaritan "paradox" discussed in the journals. Our example has the merit of showing the irrelevance of the temporal ordering of the actions involved. As the duality of tenses in (2)-(4) shows, the paradoxical result has nothing to do with 
whether or not Benjamin's act of robbery is prior to, or later than, Arthur's act of bandaging. Thus, H. P. Rickman's ${ }^{4}$ solution won't do. He has claimed that:

If $p$ implies $q$ because $q$ is the necessary consequence of $p$ and if $q$ is wrong then $p$ is wrong. If, when drunk I shall necessarily insult my host and if insulting my host is wrong then getting drunk is wrong... But if $p$ implies $q$ because $q$ is the necessary condition of $p$ and $q$ is wrong the wrongness of $p$ does not follow. If I can only apologize to my host because I have first insulted him, and insulting him is wrong it does not follow that apologizing is wrong... The condition of an action is something which necessarily precedes the action... A consequence must, of course, follow in time the commencement of the action. (p. 273)

Obviously, similar considerations show that a reference to the places where the acts $\mathrm{A}$ and $\mathrm{B}$ are (will be) performed is also of no help. ${ }^{5}$

In general, there is even no contradiction in saying some. thing of the form "X ought to do A to the man who did (will do) the wrong act B." If this statement is true and X does what he ought to do, then it follows logically that someone performed (or will perform) the wrong act B. But this is as it must be. The crucial point is that given the fact that wrong doing takes place (unfortunately though it may be), many actions are describable in such a way that from certain descriptions it will follow logically that wrong doing has occurred, or will occur. Thus, to find the principle hidden behind (P) one could try to formulate a series of conditions on the descriptions of acts which can be substituends for the variables ' $\mathrm{A}$ ' and ' $\mathrm{B}$ ' in $(\mathrm{P}$ '). This would be an interesting enterprise that should prove illu-

+ H. P. Rickman, "Escapism: The Logical Basis of Ethics," Mind, Vol. 72,1963 , pp. $273-274$.

"John Robison has also proposed a solution to the "paradox" analogous to Rickman's in "Who, What, Where, and When: A Note on Deontic Logic", Philosophical Studies, vol. XV, 1964, pp. 89.92. 
minating. However, here I want to submit that in the vague statement (P) the word 'act' has a special sense, in which it does not refer to performances, so that when the antecedent of $(\mathrm{P})$ refers to act $\mathrm{A}$ entailing act $\mathrm{B}$, we are not to think of states of affairs, or occurrences, but of something entirely different, which I will call mandates (or impera(ives). But before explaining what these are, and thus, principle (P), let us reinforce the need for mandates by dicussing: (i) a defect of the best proposal to solve the Good-Samaritan paradox without making use of a distinction between mandates and propositions, which proposal has not yet received any critical discussion, and (ii) a recent point raised by R. M. Chisholm against the standard deontic calculi.

\section{Novell-Smith and Lemmon's Solution}

P. H. Nowell-Smith and E. J. Lemmon have written an excellent discussion of the Good-Samaritan paradox in connection with the standard deontic calculus of Allan R. Anderson's. They propose a solution which consists, essentially, in separating the agents from the actions involved. The precise formulation of their solution consists in a new deontic calculus, here called N.S.L, of the standard variety (in the above sense), which is a refinement of Anderson's. They take Lewis' calculus S5 extended to quantification and introduce a particular constant predicate $\mathrm{Sx}$, which is to be interpreted as ' $\mathrm{x}$ is sanctionable' or ' $\mathrm{x}$ ought to suffer the sanction'" (p. 295). For any predicate $\varphi$ "in which $x$ ocrurs free" (their own italics) they define:

D1. $\mathrm{Fx}_{\mathrm{x}} \varphi_{\mathrm{x}}=\varphi_{\mathrm{x}} \supset \mathrm{Sx}$

D2. $0 x \varphi x=\sim \varphi \supset S x$

D1 reads: ' $x$ is forbidden to $\varphi$ ' means 'if $x \varphi s$, Sx'. D2 reads: ' $\mathrm{x}$ is obligated to $\varphi$ ' means 'if $\mathrm{x}$ does not $\varphi, \mathrm{Sx}$ '.

In N-S.L, principle $\left(\mathrm{P}^{\prime}\right)$ appears in different forms, which do not give rise to the Good-Samaritan paradox. There is no point in showing this with examples, for N.S.L

6 See their paper mentioned in footnote 4. 
eliminates the paradox at the cost of becoming seriously defective in another respect.

The formation rules of N-S.L make it impossible to formulate: (i) importante statements of ordinary deontic logic, and (ii), as a consequence, important deontic logical truths. One type of examples of (i) is furnished by

(5) It is obligatory (it ought to be the case) that someone do action $\mathrm{A}$.

Here we have a deontic operator with no particular agent indicator, while in N-S.L every deontic operator must have an indicator denoting an agent. In N-S.L we can formulate.

(6) Someone is obligated (ought) to do A.

This comes as " $(\exists x)$ (OxAx)." But (5) cannot be symbol. ized in N-S.L as "Ox( $\exists x)(A x) "$ ": this formula is not wellformed, because the formula " $(\exists x)(A x)$ " following the operator "Ox" does not contain a free occurrence of $\mathrm{x}$. This condition is precisely the one that allows Nowell-Smith and Lemon to get rid of the paradox!

The difference between (5) and (6) is extremely important. While (6) entails (5), (5) does not entail (6). And here we have a basic entailment of deontic logic that cannot be asserted, much less proven, in N-S.L.

Perhaps an instance of (5) may not be amiss. Consider the case of a bank with two assistant managers and a bank rule that requires that certain documents must be signed by one or the other, without specifying anything else. Here it is obligatory that someone sign a given document of the kind in question, but it is false that someone in particular is obligated to sign it. There is here only a collective and disjunctive obligation. If either one signs, they both discharge their responsability, neither one is liable. If neither signs, then they are both liable. ${ }^{7}$

7 The difference between (5) and (6) has turned out to be an interesting test of adequacy for several views in moral philosophy. This difference is central to a battery of objections raised by George Nakhnikian against Marcus Singer in the former's "Generalization in Ethics," Review of Metaphysics, Vol. 17, 1964, pp. 436-461. That difference is also an important weapon in a series of arguments I have formulated against certain proposals by David Falk 
In brief, Nowell-Smith and Lemmon's proposed solution of the paradox is unacceptable. We must allow for dis. junctive and conjunctive obligations, as well as for individual obligations and permissions.

\section{Chisholm's Contrary-to-Duty-Imperatives}

In a recent paper" Chisholm has argued that most existing deontic calculi are inadequate because, in his own words:

We may say, more generally, that the logics in question imply that any four statements of the following form are mutually inconsistent: (1) it ought to be that $a$; (2) it ought to be that if $a$ then $b$; (3) if not-a, then it ought to be that not- $b$; and (4) not- $a$. But most of the situations in which we can assert counter-obligation imperatives are situations in which we can also assert a set of four such statements. For we may say, of almost every action $a$, whether or not it is obligatory and whether or not it is performed: it ought to be that if a man does perform $a$ he be treated as responsible for the performance of $a$; and if he does not perform $a$, then it ought not to be that he is treated as responsible for the performance of $a$. (p. 35)

Chisholm's attack against the standard calculi is based on two theorems of these calculi; (Tl) " $\mathrm{O}(\mathrm{a} \supset \mathrm{b}) \supset(\mathrm{Oa} \supset \mathrm{Ob})$ " and (T2) "Ob $\sim 0 \sim$ b." From Chisholm's (2) and (T1) it seems to follow that $\left(2^{\prime}\right)$ "If it ought to be the case that $a$, then it ought to be the case that $b$." Clearly, from $\left(2^{\prime}\right)$ and (1) we can derive "It ought to be the case that $b$," and from this and (T2) we get "It is not the case that it ought to be that not-b." But from (3) and (4) we get

concerning the analysis of 'ought', in "Imperatives, Decisions, and Oughts: A Logico-metaphysical Investigation," Morolity and the Language of Conduct, ed. by H.N. Castañeda and George Nakhnikian, Wayne University Press, Detroit, Michigan, 1963, pp. 2566.

s Roderick M. Chisholm, "Contrary-to-Duty Imperatives and Deontic Logic," Analysis, Vol. 23, 1963, pp. 33-36. 
"It ought to be that not- $b$." Hence, we seem to have a contradiction." Yet there is a question as to how Chisholm's statements in English should be symbolized in a standard calculus. A deontic logician may consistently argue that Chisholm's statement (2) above should be symbolized as ' $\mathrm{a} \supset \mathrm{Ob}$ '. With this symbolization Chisholm's derivation of a contradiction collapses. ${ }^{10}$

Chisholm does have, nevertheless, a good point. It is more clearly brought out with non-conditional examples. Consider the natural statement made with the sentence.

(11) It is obligatory that Peter paint the table which he will bring.

The verb "will bring" expresses an act which is not meant to be said to be obligatory. It occurs inessentially, so to speak, in the scope of the deontic operator 'it is obligatory that'. Thus, an equivalent statement can be made by uttering the sentence:

(11a) Peter will bring (just) one table, and it is obligatory that he paints it.

On the contrary, a statement normally made with the sentence

(12) It is obligatory that Peter both bring one table and paint it.

is such that it cannot be made with a sentence, having its customary meanings, in which the verb 'bring' is outside the scope of a deontic operator. Now, in this case the defender of the standard deontic calculi may argue that both (11) and (11a) should be symbolized as 'p.Oq', while (12) should

9. Chisholm asserts: 'I believe that the present criticisms do not apply to the system $\left[\mathrm{M}^{*}\right]$ set forth by Hector-Neri Castañeda? Sce his "Outline of a theory on the general structure of the language of action," Theoria XXVI (1960), pp. 151.182. Chisholm's belief is true. Because in $\mathrm{M}^{*}$ there is the dis. tinction between an imperative formula (which expresses a mandate) and an indicative, Chisholm's four propositions are symbolized as follow in $\mathrm{M}^{\circ}$, where underlined letters stand for imperatives: (1) $0 a$; (2) $0(a \supset b)$; (3) $\sim a \supset 0 \sim b ;(4) \sim a$. From these formulas and theorems (T1) and (T2) we cannot derive a contradiction. From (2) we can derive $\left(2^{\prime \prime}\right)$ a $\supset 0$, but we cannot proceed to detach $0 \mathrm{~b}$, since we do not have the indicative a as a premise.

10 I owe this observation to my student Dolph Ulrich. 
be symbolized as ' $O$ (p.q)'. This is the counterpart of the move suggested above in connection with Chisholm's form (2). However, there is a difficulty here. The standard deon. tic calculi have no way of expressing the equivalence bet. ween (11) and (11a), which is a trivial, but nevertheless an important equivalence in ordinary deontic language.

To my mind the clinching proof of the distinction I want to formulate between two ways of considering actions, lies in the fact that there are cases in which an expression, even a verb, $\mathrm{E}$, which occurs inessentially (in the above sense) in the scope of a deontic operator $\mathrm{O}$ of a sentence $\mathrm{S}$ cannot be taken out of the scope of $\mathrm{O}$ in $\mathrm{S}$. That is, the statement made with a normal utterance of such a sentence $\mathrm{S}$ has no equivalent statement that can be made with the normal use of a sentence in which the expression $\mathrm{E}$ is not in the scope of a deontic operator. Examples are furnished by sentences of the form

(13) It is permitted that everybody who did (does) B do A. Here the clause 'who did (does) B' cannot be brought out of the operator 'it is permitted that'. The statements normally made with a sentence of form (13) are not equivalent to the statements normally made with the correspond. ing sentences of the form

(14) Everybody who did (does) B is permitted to do A. (The statements made with a sentence of form (13) entail, but are not entailed by, the statements made with the corresponding sentence of form (14) ). To see this suppose that our statements are about a club which has only two members, say, $a$ and $b$. Hence, (13) would amount to:

(13a) It is permitted that both if $a$ did (does) $\mathrm{B}$, he do $\mathrm{A}$ and if $b$ did (does) $\mathrm{B}$, he do A;

while

(14) would amount to

(14a) If $a$ did (does) B, he is permitted to do A, and if $b$ did (does) $\mathrm{B}$, he is permitted to do $\mathrm{A}$.

Clearly, (13a) entails (14a). But (14a) does not entail (13a): each person can have a right or permission to do 
something while lacking a right or permission to do it jointly.

Thus, the act B or the doing of B appears in (13) and in (13a) ineliminably in the scope of the deontic expression "it is permitted that", in spite of the fact that it does not occur essentially, so to speak, in such a scope. In an assertion made with sentence (13), or (13a), doing B is conceived of only as a circumstance, not as an act in that peculiar sense in which acts are subject matter of deontic considerations, or, as I shall say, as an act prescriptively considered.

\section{Acts, Circumstances, and Mandates}

There are several tests for determining whether or not an act is prescriptively considered. To simplify the exposition I must first introduce some technical terms. By a deontic operator I mean any expression of the following set, or synonymous with one of the set: 'it is obligatory (wrong, forbidden, right, permissible) that' and 'it ought (not) to be the case that' and 'it is not the case that it ought (not) to be that'. By prescriptive operator I mean any expression of the following set, or synonymous with one of the set: 'It is requested (commanded, ordered, asked) that' and '....commands (commanded, requests, requested, orders, ordered, asks, asked, begged, entreatied) that'. Now, let D be a deontic or a prescriptive operator; let $\mathrm{V}$ be a verb or a phrase that appears in a clause $\mathrm{C}$ but does not appear in the scope of a deontic or prescriptive operator in C; let $\mathrm{C}$ appear in a sentence of the form $\mathrm{D}(\mathrm{AkC})$, or $\mathrm{D}(\mathrm{CkA})$, where $\mathrm{A}$ is any clause whatever and $\mathrm{k}$ is some logical connective (like, 'and', 'or', 'if', 'unless').

Test 1. Consider a non-tautologous statement $\mathrm{S}$ made through a normal utterance with the customary meaning of the sentence $\mathrm{D}(\mathrm{AkC})$, or $\mathrm{D}(\mathrm{CkA})$. I say that the act or action denoted by V (if any) is not prescriptively considered in $S$ if $\mathrm{S}$ is equivalent to, that is, has necessarily the same truth value as, the statement $S^{\prime}$ made, or that could have been 
made, through the normal utterance with the customary meaning of the corresponding sentences $\mathrm{D}(\mathrm{A}) \mathrm{k}^{\prime} \mathrm{C}$, or $\mathrm{Ck}^{\prime} \mathrm{D}(\mathrm{A})$, or $k^{\prime} \mathrm{CD}(\mathrm{A})$, where $\mathrm{k}^{\prime}$ is some logical connective, not necessarily different from $\mathrm{k}$. (It is assumed throughout that each expression has the same meaning and referent in its several occurrences.) Also, $\mathrm{V}$ does not denote an act prescriptively considered in statement $\mathrm{S}^{\prime}$.

As an example of Test 1 , consider the sentence.

(15) It is obligatory that Mary comes or Peter calls John. It has an interesting ambiguity. In its normal meaning it may be used to make three different statements. It may be used to assert that Mary and Peter share a disjunctive obligation (of the kind mentioned in section 3). But (15) may also be used to assert that only one of them is responsible for seeing that the disjunction be actualized, the other's performance being only a circumstance, so that if neither performs only one of them is punishable. One sure way of telling which of these three possible statements is meant consists of finding out whether the statement made by the utterance of (15) is meant to be equivalent to the statement that could have been made by uttering $(15 a)$, or $(15 b)$ or equivalent to neither of these:

(15a) Unless Peter calls John, it is obligatory that Mary come [or, Mary is obligated to come];

(15b) Unless Mary comes, it is obligatory that Peter call [or, Peter is obligated to call] John.

If, for instance, the statement made with (15) is equivalent to the statement made with (15a), then in neither statement is the act denoted by 'call' prescriptively considered; the same is true of the act denoted by the expression "call John'.

Test 2. Let D be a deontic or prescriptive operator within the scope of which there appears no deontic or prescriptive operator in the sentence $\mathrm{D}(\mathrm{C})$. Delete $\mathrm{D}$ and find the imperative $\mathrm{C}^{\prime}$ corresponding to $\mathrm{C}$ in the sense that by uttering $\mathrm{C}^{\prime}$ one requests or orders the doing of precisely what one 
asserts to have the deontic character mentioned in D if one makes a normal statements $\mathrm{S}$ with the sentence $\mathrm{D}(\mathrm{C})$. Then the whole of $\mathrm{C}$, each of the verbs which are put in the im. perative mood to produce $\mathrm{C}^{\prime}$, and each of the phrases containing at least one of these verbs, denote the acts prescrip. tively in statement $S$.

The application of this test to the three normal statements that can be made with sentence (15) yields the following as corresponding imperatives:

(15ai) Mary, you come, or Peter will call [unless Peter calls] John;

(15bi) Peter, you call John, unless Mary comes;

(15ci) Mary, you come, or, Peter, you call John.

The imperative test can be applied to sentences (13) and (14). In both cases it yields the imperative "Everybody who did (does) B, do A." This is, of course, alright. From the fact that both (13) and (14) are used to make statements in which the same acts are prescriptively considered. nothing follows about the entailment relationships between the statements in question.

In other languages, e.g., my native Spanish, there is a test as follows:

Test 3. Let $\mathrm{V}$ be a verb in a clause $\mathrm{C}$ such that $\mathrm{V}$ does not appear in the scope of a deontic or prescriptive operator. Let $\mathrm{D}(\mathrm{C})$ be a sentence expressing statement $\mathrm{S}$, where $\mathrm{D}$ is a deontic or prescriptive operator. Then the acts denoted by $\mathrm{V}, \mathrm{C}$ and any phrase or subclause of $\mathrm{C}$ containing $\mathrm{V}$ are acts prescriptively considered in the statement $S$, if $\mathrm{V}$ is in the subjunctive mood.

The three different types of statements that can be made with sentence (15) could be distinguished as follows by means of Test 3 :

(15as) It is obligatory that Mary come or Peter calls John;

(15bs) It is obligatory that Mary come or Peter call John; 
(15cs) It is obligatory that Mary come or Peter call John.

It must be noted, however, that Test 3 is in English" ${ }^{11}$, only sufficient, but not necessary. In English we use the infinitive, not the subjunctive as, e.g., Spanish does, in sentences like 'I ordered (commanded) Peter to do it.'

By mandate (or imperative) I mean a command, an order, a petition, a request, an entreaty.

Test 4. If a sentence $\mathrm{C}$ contains a verb $\mathrm{V}$ in the imperative mood and a normal utterance of $\mathrm{C}$ expresses a mandate $\mathrm{M}$, then the action or act mentioned in $\mathrm{V}$ and the acts mentioned in the phrases of $C$ containing $V$ are all prescriptively considered in $M$.

Test 5. If a statement or mandate $\mathrm{S}$ is formulated through the utterance of a complex sentence $\mathrm{C}$, then if $\mathrm{C}$ ' is a clause or sub-sentence of $\mathrm{C}$ and $\mathrm{C}$ ' formulates a statement or mandate $\mathrm{M}$, then every act or action prescriptively considered in $\mathrm{M}$ is also prescriptively considered in S.

These tests provide a recursive characterization of what I mean by 'prescriptively considered'. I will attempt no more precision here.

Let $\mathrm{C}$ be a sentence containing a verb in the imperative mood, and let $\mathrm{C}$ formulate a mandate $\mathrm{M}$. Then I define $\mathrm{A}$ is the act characteristic of $M$ (with respect to $\mathrm{C}$ ) if and only if $\mathrm{A}$ is the act denoted by the whole of sentence $\mathrm{C}$.

\section{A Fundamental Deontic Principle}

The preceding discussion has shown the intimate connection between mandates and acts prescriptively considered. This suggests that the entailments between deontic assertions

11 That the subjunctive is still a valid test in English was pointed out by Professor Ruth Barcan Marcus in her comments of an earlier version of this paper read at the meetings of the Eastern Division of the American Philosophical Association, Boston, December, 1964. 
should follow, not all the implication routes of the actions considered in those assertions, but only the implication routes of the actions prescriptively considered in them. Thus, I submit that a more precise statement of the principle which $(\mathrm{P})$ above abbreviates is:

$\mathrm{P}^{*}$. If mandate $\mathrm{M}$ entails mandate $\mathrm{M}^{\prime}$ and $\mathrm{A}$ is the act characteristic of $\mathrm{M}$ while $\mathrm{B}$ is the act characteristic of $\mathrm{M}$ ', then: (a) if $\mathrm{A}$ is obligatory (permissible), $\mathrm{B}$ is obligatory (permissible),

and

(b) if $\mathrm{B}$ is forbidden (wrong), $\mathrm{A}$ is also forbidden (wrong).

This principle is not touched by the counter-example that section 2 destroyed ( $\left.\mathrm{P}^{\prime}\right)$. On the one hand, the mandate "Arthur, bandage the man robbed (who will be robbed) by Benjamin" does not entail the mandate "Benjamin, rob someone." On the other hand, although the mandate "Arthur, bandage the man robbed (who will be robbed) by Benjamin" does entail the statement (or state of affairs) "Benjamin robbed (will rob) someone," the latter, like any other statement (or state of affairs), is not a mandate. Thus, in neither case do we have an instance of $\mathrm{P}^{*}$, so that here is no absurdity derivable from $\mathrm{P}^{*}$.

\section{Conditions for Adequate Deontic Calculi}

Principle $\mathrm{P}^{*}$, or $(\mathrm{P})$ of Section 2, can only be formalized in a deontic calculus which either (i) has only one sort of sentential expressions, all of which are to be interpreted as denoting mandates or acts prescriptively considered, or (ii) has two sorts of sentential expressions: one denoting states of affairs and the other denoting mandates. Obviously, calculi of type (i) are too simple. ${ }^{12}$ They are unable to

\footnotetext{
12, A very simple calculus of this sort is the one Von Wright formulated in the papers mentioned in footnote 1. In this calculus expressions of the

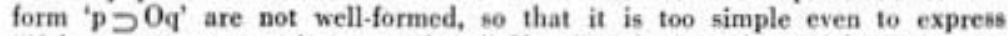
"if he comes, you ought to see him." Von Wright has changed his views on deontic logic. He has set up new, very different ealeuli in Norm and Action
} 
handle even trivial inferences of the form "If he comes, you ought to talk to him; he is coming, hence, you ought to talk to him." In this inference, the clause 'he comes' denotes a state of affairs, while the infinitive phrase 'talk to him' denotes an act prescriptively considered and must be understood as relating to a mandate, hence, as presupposing an imperative sentences. Thus, if the preceding discussion is correct, we ought to devise calculi for deontic logic in which the distinction between mandates and states of affairs is made right at the beginning by means of two kinds of sen. tential expressions.

Furthermore, if the preceding discussion is correct, then deontic and prescriptive operators ought not to be treated as modal operators to be prefixed to sentences or clauses denoting statements or statement-functions. On the contrary, deontic and prescriptive operators must be viewed rather as prefixes of sentences or clauses denoting mandates or mandate-functions, or at any rate, as prefixes of expressions denoting acts prescriptively considered. (Here is the profound insight that philosophers like Kant and Ayer and Ste. venson and Hare have been expounding in their several claims that oughtstatements are a good deal like imperative assertions. ${ }^{13}$ )

\section{Deontic Calculi $D^{*}$}

The crucial distinction between acts qua circumstances and acts qua prescriptively considered, and the above mentioned basic connection between mandates and deontic as. sertions, have been formalized in a deontic calculus $\mathrm{M}^{*}$

The Humanities Press, New York, 1963). These caleuli have interesting fea. tures, but are net helpful as formalizations of propositional deontic logic, as 1 argue in "The Logic of Change, Action, and Norms," The Journal of Philosophy, vol. LXII, 1965, pp. 333-344.

1a For a most detailed discussion of the connections between imperatives. decisions, and ought-statements, see W. Sellars, "Imperatives, Intentions and the Logie of 'Ought'," and H.N. Castañeda, "Imperatives, Decisions and Oughts," both in Castañeda and Nakhnikian, eds., Morality and the Language of Conduct, mentioned in footnote 8 above. 
proposed by H. N. Castañeda. " Here 1 want to introduce a pair $\mathrm{D}^{*}$ of calculi, $\mathrm{D}^{*} .1$ and $\mathrm{D}^{*} .2$, obtained by making some changes in $M^{*} . D^{*}$ is an even better formalization of ordinary deontic logic. The central ideas represented in both $\mathrm{M}^{*}$ and $\mathrm{D}^{*}$ are: ${ }^{15}$

I. The distinction between formulas expressing circumstances, called indicatives, and formulas expressing acts prescriptively considered, called imperatives or imperative-resolutives;

II. the claim that imperatives have the same logical properties that indicatives have $;^{16}$

III. the view that deontic operators are modal operators which apply to imperatives to yield indicatives; that is, e.g., "It is obligatory that Mary comes." is an indicative built out of the imperative "Mary, come";

IV. the view that mixed conjunctions, disjunctions, conditionals, that is, compounds one component of which is imperative and the other is indicative, are imperative compounds.

14 See footnotes 3 and 10 above.

15 The main differences between $D^{*}$ and $M^{*}$ are as follows: (1) in $D$ the operator 'it is obligatory that' is symbolized with 0 instead of ' $\mathrm{K}$ '. (2) In $\mathrm{D}^{\text {* }}$ we form "atomic" imperative-resolutive formulas by underlining the individual sign denoting the agent, instead of putting square brackets to denote imperative predication as in $\mathrm{M}^{*}$. The origin of this change lies in my friends, Edmund Gettier and George Nakhnikian's having pointed out to me that "Al is obligated to kill Burt" does not entail "Burt is obligated to be killed by Al" Al's obligation need not be accompanied by any obligation on Burt's part in this matter. Thus, while "Al is killing Burt" and "Burt is being

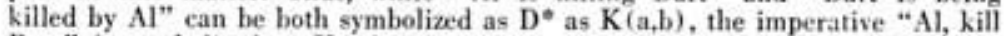
Burt" is symbolized as $\mathrm{K}(a, \mathrm{~b})$ and "Burt, let Al kill you" is symbolized by $\mathrm{K}(a, \mathrm{~b})$. Accordingly, we can distinguish in $\mathrm{D}$ * between " $\mathrm{Al}$ ought to kill Burt," symbolized as $\mathrm{OK}(\mathrm{a}, b)$, and "Burt ought to (let himself) be killed by $\mathrm{Al}, "$ symbolized as $\mathrm{OK}(\mathrm{a}, b)$, (3) Axiom A43 has been replaced. (4) A special axiom for quantification has been dropped, since it proved to be derivable. (5) In $\mathrm{D}^{*}$ the contrast between $\mathrm{D}^{*} .1$ and $\mathrm{D}^{*} .2$ has been made explicit.

${ }_{16}$ For a defence of this claim see R. M. Hare, The Language of Morals, Claredon Press, Oxford, England, 1952, pp. 24ff, H.-N. Castañeda, "Imperative Reasonings," Philosophy and Phenomenological Research, Vol. 21, 1960, pp. 21-49, and Lars Bergström, Imperatices and Ethics, Stockholm University Press, Stockholm, 1962, Ch. 4. 
For example: "Mary, come unless Peter stays" is an im. perative, while "Peter stays" and "it is obligatory that Mary comes or Peter stays" are indicatives.

Now; let " $F\left(x_{1}, x_{2}, \ldots, d_{n}\right)$ " be an elementary indicative matrix of the sort studied in ordinary logic, where quota. tion marks are used like Quine's corners. The primary formation rule of $\mathrm{D}^{*}$ for imperatives is:

" $F\left(x_{i}, \ldots, x_{i-1}, x_{i}, x_{i+1}, \ldots, x_{i n}\right)$ " is an imperative resolutive; where only $x_{1}$ is underlined [and $x_{1}$ is a variable ranging over persons, or a personal name or description].

The idea is that $x_{1}$ denotes the subject of an act prescripvely considered.

Naturally, negations, conjunctions, universalizations, ete., of imperatives are imperative, and by IV so are all mixed compounds.

The basic rule of formation of $\mathrm{D}^{\mathrm{*}}$ for deontic formulas is: if $A$ is an imperative formula, then " $O(A)$ " is a deontic indicative, where $\mathrm{O}$ stands for "It is obligatory that" or "It ought to be the case that." Compounds of indicatives and deontic formulas are also deontic indicatives. Negations and universalisations of deontic indicatives are also deontic indicatives. From now on underlining will indicate impera. tiveness.

Axiom-schemata of $D^{*} .1$ : (A), (B) and (C): of $D^{*} 2$ : (A), (B), and $\left(\mathrm{C}^{\prime}\right)$ :

(A). Axioms for propositional logic, which are general. ized to imperative-resolutives;

(B) Axioms for quantificational logic, similarly generalized;

(C) Axioms for the logic of prima-facie obligations, oughts, etc. ${ }^{17}$

17 The logic of prima facie obligations, duties, ete. is required to understand the logie of conflicts of duties. These matters are discussed in H.N. Casta. ñeda, "A Theory of Morality," Philosophy and Phenomenological Research, Vol. XVII, 1957, pp. 339.352, in which the earlier deontic system $\mathrm{N}^{*}$ should be replaced by the present systems $D^{\bullet} 1$ and $D^{*} 2$. 
A40. $\sim \mathrm{O} \sim(\mathrm{x})(\mathrm{O}(A) \supset(A))$

A42. $\mathrm{O}(A \supset B) \supset(\mathrm{O}(A) \supset \mathrm{O}(B))$

$\mathrm{A} 43 . \mathrm{O}(\mathrm{B} \supset A) \supset(\mathrm{B} \supset \mathrm{O}(\mathrm{A}))$, where $\mathrm{B}$ is an indicative.

$\left(\mathrm{C}^{\prime}\right)$ Axioms for the logic of the overriding ought: ${ }^{18}$ A41. $\mathrm{O}(A) \supset A$ and $\mathrm{A} 42-\mathrm{A} 43$.

No special axioms for quantified deontic logic are required, besides $\mathrm{A} 40$.

Definitions:

Def. 1. $\mathrm{P}(A)=\sim 0 \sim(A)$

Def. 2. $\mathrm{F}(A)=\mathrm{O} \sim(A)$.

The usual definitions of 'proof' and 'theorem' are adopted.

Rules of Inference:

R1. Modus Ponens,

DR. Rule of deontic inference: If an imperative-resolutive $A$ is a theorem of $\mathrm{D}^{*}, " \mathrm{O}(A)$ " is a theorem of $\mathrm{D}^{*}$.

UG. Universal generalization:

(1) If $\mathrm{A}$ is theorem, so is (x) (A);

(2) If $A$ is a theorem, so is $(\mathrm{x})(A)$, provided that axiom A4l is not used in the proof of $A$.

Principle $\mathrm{P}^{*}$ of section 6 above appears in $\mathrm{D}^{*}$ as:

$\mathrm{P} *$.1. " $A \supset B$ " (or " $\sim A \vee B$ ") is a theorem of $\mathrm{D}$, then " $\mathrm{O}(A) \supset \mathrm{O}(B)$ " and " $\mathrm{F}(B) \supset \mathrm{F}(\mathrm{A})$ " are theorems of $D^{*}$.

P*.1 follows directly from DR and A42.

18 For the original contrast between prima facie oughts and unqualified oughts see W. D. Ross, The Right and the Good, Claredon Press, Oxford, 1930 , pp. 19ff. For my way of drawing the contrast see my "Oughts and Moral Oughts," Archice für Rechts-und Sozialphilosophie, 1964. 
Some theorems which can be proven in D*:

T1. $\mathrm{O}(A \cdot B)=(\mathrm{OA} \cdot \mathrm{O} B)$

T2. $\mathrm{O}(\mathrm{A} \supset B)=(\mathrm{A} \supset \mathrm{O} B)$

T3. $\mathrm{P}(A \supset B)=(\mathrm{A} \supset \mathrm{P} B)$

T4. $\mathrm{O}(A \supset \mathrm{B})=(\mathrm{P} A \supset \mathrm{B})$

T5. $\mathrm{P}(A \supset \mathrm{B})=(\mathrm{O} A \supset \mathrm{B})^{19}$

T6. $\mathrm{P}(A \vee B)=(\mathrm{P} A \vee \mathrm{P} B)^{30}$

T7. $\mathrm{F}(A) \supset \mathrm{F}(A \cdot B)$

T8. $\mathrm{F}(A \cdot \mathrm{B})=(\mathrm{B} \supset \mathrm{F} A)$

T9. $\mathrm{O}(A \cdot \mathrm{B})=(\mathrm{OA} \cdot \mathrm{B})$

T10. $\mathrm{P}(A \cdot \mathrm{B})=(\mathrm{P} A \cdot \mathrm{B})$

T11. $\mathrm{O}(\mathrm{x}) \mathrm{A} x \supset(\mathrm{x}) \mathrm{O} \mathrm{A} x$

T12. ( $\exists \mathrm{x}) \mathrm{PA} x \supset \mathrm{P}(\exists \mathrm{x}) \mathrm{A} x$

T13. $\mathrm{O}(\mathrm{x})(\mathrm{A} \supset \mathrm{B} x) \supset(\mathrm{x})(\mathrm{A} \supset \mathrm{O} \mathrm{B} x)$

T14. $\mathrm{P}(\mathrm{x})(\mathrm{Bx} \supset \mathrm{A} x) \supset(\mathrm{x})(\mathrm{Bx} \supset \mathrm{P} A x)^{z 1}$

10. In her discussion mentioned in footnote 11, Professor Marcus requested an example in English of this theorem. I proposed: "It is permited that the following be the case: You open for business today only if today is not a holiday" is equivalent to "If you are required (obligated) to open for business today, then today is not a holiday."

20. Professor Von Wright has attacked this equivalence in Norm and Ac. tion, pp. 182.181. His arguments are, however, inconclusive, as I show in my paper mentioned in footnote 12.

at This is the erucial entailment from (13) to (14) at the end of Section 4. 


\section{RESUMEN}

1. El propósito de este ensayo es contribuir a la comprensión del concepto de "acto" y del principio de lógica deóntica (P): "Si un acto A implica un acto B, la obligatoriedad de A implica la obligatoriedad de B". Se mostrará que, en este principio, "acto" debe entenderse como "acto prescriptivamente considerado" y se propondrán cinco pruebas para caracterizar esa clase de actos.

La discusión de los "actos prescriptivamente considerados" conducirá a una crítica del enfoque usual en las formalizaciones de ló. gica deóntica, que no logran formalizar la distinción entre los actos prescriptivamente considerados y otros actos. El fin será esbozar un nuevo cálculo deóntico que carezea de ese defecto.

2. En el principio (P) de lógica deóntica antes citado, parece natural interpretar "acto A" como "una posible situación objetiva (state of affairs) en que un agente determinado ejecuta la acción A". Pero esta interpretación es falsa porque la traducción de (P) en esos términos es inconsistente con situaciones deónticas de la vida ordinaria. El análisis de un contraejemplo emparentado con la co. nocida paradoja del "buen samaritano", muestra que, si seguimos esa interpretación, llegamos a contradicciones.

En (P) la palabra "acto" tiene, pues, otro sentido: no se refiere a la ocurrencia de determinadas situaciones objetivas, sino a man. datos (o imperativos). Antes de demostrarlo, conviene reforzar la necesidad de esta interpretación, con la siguiente discusión.

3. P.H. Nowell-Smith y E.J. Lemmon han propuesto una solución a la paradoja del "buen samaritano" que consiste en separar los agentes de las acciones que ejecutan. Esta distinción se formula en un nuevo cálculo deóntico que permite eliminar la paradoja. Pero esta ventaja se paga con otras deficiencias: no puede formular algunos enunciados y algunas verdades importantes de la lógica deóntica ordinaria. Por ejemplo, es incapaz de formalizar el enunciado: "es obligatorio que alguien ejecute la acción A"; ni tampoco la implicación de este enunciado a partir del antecedente: "alguien está obligado a hacer A". Luego la solución a la paradoja, propuesta por Nowell-Smith y Lemmon, es inaceptable.

4. Por otra parte Chisholm ha criticado la mayoría de los cálculos deónticos porque entrañan la inconsistencia de algunos enunciados que, sin embargo, son exigidos en ciertas situaciones. Una discusión pormenorizada de esta crítica permite concluir lo siguiente: si bien puede argüirse que al aceptar otra simbolización de uno de 
los enunciados que menciona Chisholm, desaparecería su aparente inconsistencia $y$, por lo tanto, el mayor peso de la crítica de Chisholm, con todo, hay un punto importante de esa crítica que debe destacarse. Aparece en algunos ejemplos de expresiones no-condicionales en las cuales hay verbos que ocurren de modo inesencial en el alcance del operador deóntico. Hay casos en que una oración S en la que un verbo ocurre inesencialmente en el alcance de un operador deóntico no es equivalente a una oración $\mathrm{S}^{\prime}$ en que ese verbo se coloque fuera del alcance del operador deóntico. Por ejemplo, se muestra que "es permitido que quienquiera haga $\mathrm{B}$, haga $\mathrm{A}$ " (en que la acción $\mathrm{B}$ ocurre inesencialmente en el alcance del operador "es permitido que"), no es equivalente a "a quienquiera haga B le es permitido que haga A" (en que la acción B está fuera del alcan. ce del operador). Asi, el acto $\mathrm{B}$ no puede ser eliminado del alcance del operador), pese a que no ocurre esencialmente, por así decirlo, en ese alcance. Luego, hay que pensar que, en las aseveraciones hechas con esas oraciones, la acción B es concebida sólo como una circunstancia, no como un acto objeto de consideraciones deónticas, o bien como un acto prescriptivamente considerado.

5. Pueden establecerse varias pruebas para determinar cuando un acto es prescriptivamente considerado. Veamos, por ejemplo, la primera prueba: simbolicemos por D un operador deóntico o prescriptivo (tal como "es obligatorio que" o "es requerido, ordenado, etc., que"); por $\mathrm{V}$ un verbo o frase que aparece en la clásula $\mathrm{C}$ fuera del alcance del operador $\mathrm{D}$; por $\mathrm{A}$, cualquier cláusula; por $\mathrm{k}$ cual. quier conectiva lógica. Consideremos una oración no tautológica $\mathrm{S}$, expresable como $\mathrm{D}(\mathrm{AkA})$ o $\mathrm{D}(\mathrm{CkA})$. Diremos que una acción denotada por $\mathrm{V}$ no es prescriptivamente considerada en $\mathrm{S}$ si lo aseverado en $\mathrm{S}$ es equivalente a lo aseverado por las oraciones $\mathrm{D}(\mathrm{A}) \mathrm{k}^{\prime} \mathrm{C}$ o $\mathrm{Ck}^{\prime} \mathrm{D}(\mathrm{A})$ o $\mathrm{k}^{\prime} \mathrm{CD}(\mathrm{A})$, en que $\mathrm{k}^{\prime}$ es una conectiva lógica cualquiera, no necesariamente diferente de $\mathrm{k}$. Entonces, $\mathrm{V}$ no denota un acto prescriptivamente considerado.

De modo semejante, se establecen otras cuatro pruebas para determinar cuando un acto es prescriptivamente considerado.

6. Las pruebas anteriores muestran una conexión íntima entre mandatos y actos prescriptivamente considerados. Esto sugiere que las implicaciones entre enunciados deónticos deben seguir sólo las vias de implicación de las acciones prescriptivamente consideradas. Entonces, puede enunciarse con mayor precisión el principio deón. tico (P) antes citado: "Si un mandato $\mathrm{M}$ implica un mandato $\mathrm{M}$ ', si $\mathrm{A}$ es el acto característico de $\mathrm{M}$ y $\mathrm{B}$ el acto característico de $\mathrm{M}^{\prime}$, entonces: a) si A es obligatorio, B es obligatorio, y b) si B está prohibido, A también está prohibido". Esta formulación del princi- 
pio - llamémosla $\left(\mathrm{P}^{*}\right)$ - no cae en las dificultades señaladas en el parágrafo 2.

7. El principio anterior podría formalizarse en un cálculo deón. tico con una sola clase de expresiones que denotaran mandatos o actos prescriptivamente considerados. Pero éste sería un cálculo de. masiado simple, incapaz de habérselas con inferencias, aun triviales, que incluyeran una cláusula denotativa de una situación objetiva (state of affairs). Por ejemplo, no podría formalizarse en él un enunciado como el siguiente: "Si él viene, debes hablar con él; vie. ne, luego debes hablar con él", en que "él viene" denota una situa. ción objetiva y "hablar con él" un acto prescriptivamente conside. rado. Por lo tanto, es menester un cálculo en que pueda hacerse la distinción entre mandatos (o actos prescriptivamente considera. dos) y situaciones objetivas, utilizando dos tipos distintos de expre. siones.

Por otra parte, los operadores deónticos y prescriptivos no deben ser tratados, entoces, como operadores modales prefijados a cláu. sulas que expresan aseveraciones, sino como prefijos de cláusulas u oraciones que expresan mandatos o de actos prescriptivamente con. siderados. (Lo cual las asemeja a enunciados imperativos.)

8. Las distinciones señaladas y la conexión entre mandatos y enunciados deónticos ha sido ya formalizada en un cálculo deóntico M* propuesto por el autor. Ahora se introduce un par de cálculos, $\mathrm{D}^{*} .1$ y $\mathrm{D}^{*} .2$, obtenidos al proponer algunos cambios en $\mathrm{M}^{*}$ : Las ideas centrales de $\mathrm{M}^{*}$ y $\mathrm{D}^{*}$ son:

1] Se distingue entre fórmulas que expresan circunstancias, llamadas indicatitos, y fórmulas que expresan actos prescriptivamente considerados, llamadas imperativos o imperativos-resolutivos.

2] Los imperativos tienen las mismas propiedades lógicas que los indicativos.

3] Los operadores deónticos se consideran como operadores modales que se aplican a imperativos para obtener indicativos.

4] Compuestos de un componente imperativo $y$ otro indicativo (conjunciones mixtas, disyunciones, condicionales, etc.) son compuestos imperativos.

La regla de formación básica en $\mathrm{D}^{*}$ es: $\mathrm{Si} A$ es una fórmula im. perativa, entonces " $\mathrm{O}(A)$ " es un indicativo deóntico, en que " $O$ " significa "es obligatorio que".

Se establece un esquema de axiomas para $D^{*} .1$ y $D^{*} .2$, que com. prende: axiomas de la lógica proposicional y de la lógica cuantificacional para ambos; axiomas de la lógica de la obligación prima facie, para $\mathrm{D}^{\bullet} .1, \mathrm{y}$ de la lógica de la obligación no eualificada, para $\mathrm{D}^{*} .2$.

Se da dos definiciones de indicativos deónticos — "P $(A)$ " ("A 
está permitido") y "F $(A)$ " (" $A$ está prohibido") - en función de "O $(A)$ ".

Las reglas de inferencia comprenden: el Modus Ponens, una regla de inferencia deóntica ("Si un imperativo-resolutivo $A$ es teorema de $D^{*}, \mathrm{O}(A)$ es teorema de $\mathrm{D}^{*}$ ) y la regla de generalización universal.

El principio $\left(\mathrm{P}^{*}\right)$, arriba citado, se sigue de uno de los axiomas de $D^{*} .1$ y de la regla de inferencia deóntica. Puede formular. se asi: $\mathrm{Si}$ " $A \supset B$ " es un teorema de $\mathrm{D}$ ", entonces "O $(A) \supset \mathrm{O}(B)$ " y " $\mathrm{F}(B) \supset \mathrm{F}(A)$ " son teoremas de $\mathrm{D}$ *.

Por último, se exponen varios teoremas que pueden ser demos. trados en $D^{*}$. 